\title{
Los serotipos de alto riesgo del papilomavirus humano son necesarios aunque no suficientes para el desarrollo de displasia de alto grado
}

Relation of human papillomavirus status to cervical lesions and consequences for cervical-cancer screening: a prospective study. Nobbenhuis MA, Walboomers JM, Helmerhorst TJ, et al. Lancet 1999; 354: 20-25.

\section{Objetivo}

Determinar la relación entre la infección por virus del papiloma humano de alto riesgo (HPV-AR) y el desarrollo de cáncer de cuello uterino.

\section{Diseño}

Estudio de cohorte.

\section{Lugar}

Consultorio de colposcopía del Free University Hospital de Amsterdam entre junio de 1990 y diciembre de 1992, seguidas por un tiempo mediano de 33 meses.

\section{Pacientes}

Se incluyeron 353 mujeres derivadas al consultorio de colposcopía por PAP anormal. Fueron criterios de inclusión: discariosis leve, moderada o severa en el PAP, edad entre 18 y 55 años, ausencia de antecedentes de patología cervical, de exposición prenatal al dietiletilbestrol o coexistencia de cáncer extracervical, y suficiente dominio del idioma holandés o inglés.

\section{Evaluación de factores de riesgo}

Las variable en estudio fue el testeo de la existencia de infección por HPV-AR mediante PCR (reacción en cadena de la polimerasa) identificando los 14 tipos virales de alto riesgo.

\section{Medición de resultados principales}

El seguimiento, cada 3-4 meses, se realizaba mediante PAP, colposcopía +/- biopsia. Se consideró como resultado de interés la progresión clínica definida como desarrollo de CIN3 (neoplasia intraepitelial cervical de alto grado o discariosis severa) cubriendo tres o más cuadrantes de la colposcopía, o PAP sospechoso de cáncer cervical.

\section{Resultados principales}

Se enrolaron 353 mujeres las que presentaban: 56 (16\%) discariosis severa y $297(84 \%)$ discariosis leve/moderada. Del total, 233 $(66 \%)$ eran HPV-AR positivas, 13 presentaban HPV de otros tipos, y 31 tenían múltiples tipos. De las 120 negativas al inicio, 39 adquirieron HPV-AR durante el seguimiento.

En 33 mujeres se vió progresión clínica (30 colposcopías sospechosas de CIN3 y 3 PAP sospechosos de cáncer microinvasor), todas con infección persistente. No se registró progresión en las HPV-AR negativas. En 103 mujeres en las que se llegó al diagnóstico histo lógico de CIN3, 100 eran positivas para HPV-AR al inicio. De los 3 CIN3 negativos al inicio 2 contrajeron infección que se hizo persistente y una se perdió del seguimiento luego de los 2 controles iniciales negativos.

La Tabla siguiente muestra los OR para el desarrollo de CIN3 y la validación de la repetición a los 6 meses del PAP o de la determinación de HPV-AR por PCR en pacientes con discariosis leve o moderada en el PAP inicial.

\begin{tabular}{l|c|c|c|c|c}
\hline & $\begin{array}{c}\text { Odds ratio para el } \\
\text { desarrollo de CIN3 } \\
(\text { IC95\%) }\end{array}$ & Sensibilidad & Especificidad & $\begin{array}{c}\text { Cociente de } \\
\text { Probabilidad } \\
\text { Positivo* }\end{array}$ & $\begin{array}{c}\text { Cociente de } \\
\text { Probabilidad } \\
\text { Negativo* }\end{array}$ \\
\hline PAP & $3.6(2-6.5)$ & 0.70 & 0.61 & 1.8 & 0.49 \\
\hline HPV-AR & $61.0(15-250)$ & 0.97 & 0.65 & 2.8 & 0.05 \\
\hline
\end{tabular}

Datos calculados por EVIDENCIA

\section{Conclusiones}

La infección persistente por HPV-AR es necesaria para el desarrollo y mantenimiento de CIN3.

Las mujeres con discariosis severa en el PAP deben ser referidas al especialista, mientras que las con discariosis leve/moderada deberían serlo de contar con HPV-AR positivo persistente.

\section{COMENTARIO}

El Carcinoma de Cuello Uterino (CCU), claramente vinculado causalmente a la infección por Papilomavirus Humano de los tipos de Alto Riesgo es el segundo cáncer en la mujer en todo el mundo. Los programas de tamizaje o rastreo han demostrado ser efectivos en reducir su incidencia, pero quedan aún por definir varios puntos como ser, entre otros, el intervalo entre controles y la conducta ante una citología anormal.

El grupo de Walboomers y Meijer ha trabajado desde hace ya largo tiempo sobre el potencial valor que la determinación de la presencia de HPV-AR puede tener en los protocolos de tamizaje del cáncer cervical. Este grupo reúne dos condiciones particulares: en primer lugar comenzó con los estudios en 1990, lo que hoy le permite contar con un importante seguimiento de su población, y en segundo lugar, su laboratorio es considerado una de las referencias en los que a PCR para HPV se refiere.

Las conclusiones del trabajo se ajustan al diseño y los resultados, y son coincidentes con otras publicaciones aparecidas recientemente. Tal vez lo más interesante de sus conclusiones tenga que ver con su propuesta de manejo vinculada a las observaciones presen- tadas, en las cuales proponen: ante un PAP con discariosis severa (CIN3 para nuestro medio) derivación al especialista; ante un PAP con discariosis leve/moderada (CIN1 y 2 para nuestro medio) determinar HPV-AR y repetir a los 6 meses, en los casos en que ambas determinaciones fueran negativas o se negativice la segunda la paciente pasa a seguimiento habitual, mientras que la que es negativa en el primer test y positiva en el segundo deberá reevaluarse a los 6 meses para actuar en consecuencia.

De todas maneras no debe perderse de vista que las realidades de costos en nuestro medio son diferentes (las determinaciones de HPV-AR por PCR son caras y la colposcopía es muy barata), así como que la confiabilidad de las determinaciones de PCR para HPV debería ser sometida a un adecuado control de calidad que nos permita depositar la confianza en sus resultados.

A la luz de las evidencias actuales, que dejan pocas o ninguna duda sobre el rol causal, necesario aunque no suficiente, del HPV-AR en la génesis del CCU, parece claro que las mujeres efectivamente HPV-AR negativas pueden ser consideradas de bajo riesgo y ser controladas en forma similar a la población general.

\section{Dr. Gustavo Amestoy}

Unidad de Patología Cervical, Dpto. de Ginecología y Obstetricia. CEMIC. 